\title{
Can an Autonomous Form of Peer Feedback in Physical Education Enhance Students' Motivation?
}

\author{
Lars Domino Østergaard1, Mikkel Curth² \\ ${ }^{1}$ Centre for Health Science Education and Problem Based Learning, Department of Health Science and \\ Technology, Aalborg University, Aalborg, Denmark \\ ${ }^{2}$ Nordjyllands Idrætshøjskole, Brønderslev, Denmark \\ Email: ldo@hst.aau.dk
}

Received 16 August 2014; revised 10 September 2014; accepted 6 October 2014

Copyright (C) 2014 by authors and Scientific Research Publishing Inc.

This work is licensed under the Creative Commons Attribution International License (CC BY). http://creativecommons.org/licenses/by/4.0/

cC) (7) Open Access

\begin{abstract}
This paper addresses the potential of creating a motivational climate by introducing an autonomous form of peer feedback as a way to enhance autonomy support, and by doing so motivate and stimulate students to engage in physical education. In an action research case study, 14 students (Male = 8, Female $=6$ ) from a Danish sports folk high school were introduced to autonomy support by giving and receiving peer feedback during a volleyball unit. Qualitative data including student observations, interviews, and student self-report logbooks were analysed, and emergent factors such as the students own choice in the peer feedback situation, the challenges the students were confronted and the context, in which the feedback was given was related to the psychological needs autonomy, competences and relatedness. The conclusion of this study is that peer feedback not only motivates the students to engage in physical activities, but also contributes to students' learning and improving of volleyball skills. Further research is needed to test the applicability of these results in other contexts.
\end{abstract}

\section{Keywords}

Motivation, Psychological Needs, Autonomy, Physical Education, Peer Feedback

\section{Introduction}

In physical education (PE), as well as in other subjects, it is important that children are motivated to engage in activities and to enhance their learning outcomes. Unfortunately, in many western countries the students' moti- 
vation for being active in school PE declines with age (Gottfried, Fleming, \& Gottfried, 2001; Munk \& von Seelen, 2012; Xiang et al., 2003). This decline leads to problems in the students' development and maintenance of physical skills (Strong et al., 2005), reduces their motivation to engage in leisure time physical activities (Cox, Smith, \& Williams, 2008), and in the long run influences the students' health with consequences such as obesity (Ross, Freeman, \& Janssen, 2000) and cardiovascular diseases (Williams, 2001). Among the attempts to counteract the above enumerated tendency (for a review, see Hagger, 2012), several groups of researchers have set out to create a positive motivational climate in physical education to involve and activate the students (Gutiérrez, Ruiz, \& López, 2010; Martin, Rudisill, \& Hastie, 2009). One way of creating a positive motivation climate and, hence, a good learning environment is to work with student interrelationships as seen in peer feedback.

\subsection{Peer Feedback in Physical Education}

Although not much research has been done on peer feedback in PE and its relation to motivation, some general perspectives are found in Ladd, Herald-Brown and Kochel's study (2009), in which the authors describe how the engagement of children and adolescents in schools is influenced by being with peers and working with them. In relation to physical activity, factors as, for example, cooperation, autonomy support, and evaluation of competence in a climate where peers supported each other were found to affect the general motivational climate (Vazou, Ntoumanis, \& Duda, 2005). This study is supported by other investigations of peer support and motivational climate in physical activity that have been conducted in school PE settings (e.g., Jõesaar, Hein, \& Hagger, 2011; Murcia et al., 2008), indicating that peer support as feedback in PE can positively influence students' motivation for the subject. In another study, where peer feedback was a part of collaborative learning, Dyson (2002) followed third and fourth grade students in PE for two years. He found that peer feedback not only had a positive influence on the students' learning of basic skills, but that it also enhanced the students' ability to analyse and reflect on their own and their peers' achieved skills.

Other studies have dealt with other forms of peer relationships. Cox \& Ullrich-French (2010) have shown that a positive peer relationship in PE, even with low teacher support, is associated with optimal physical education experiences. Peer relationship such as peer tutoring, peer coaching and peer teaching in PE at different levels (d'Arripe-Longueville et al., 2002; Layne \& Hastie, 2012; Parker \& Sharpe, 1995; Ward \& Lee, 2005) has shown a positive impact on the students' engagement, attitude, autonomy and feeling of competence. In sport settings (Hagger et al., 2005; Wallhead, Hagger, \& Smith, 2010) results have revealed peer relationship as an important motivation factor.

The present study associates peer feedback with peer teaching (Siedentop, 1998) and to a minor degree reciprocal teaching style (Mosston \& Ashworth, 2008) giving peer feedback in this project a more autonomous and less teacher-controlled form. The students worked in pairs and were given a degree of freedom to work with self-elected goals in PE within a selected frame (optimizing of volleyball skills) to enhance their psychological need satisfaction and their motivation for exercising volleyball skills by implementing a high degree of autonomy and self-control. Subsequently, the aim of the study was to investigate how an autonomous form of peer feedback would influence the students' behaviour and attitude to perform volleyball exercises as sign of motivational changes.

\subsection{Motivation and Physical Education}

As personal, social and cultural factors in school settings influence the motivational climate, the self-determination theory, (SDT; Deci \& Ryan, 2012; Reeve, Deci, \& Ryan 2004), which adopts a multidimensional perspective on motivation, was chosen as the conceptual framework for this study. The SDT addresses how individual inherent growth tendencies and psychological needs interact with the sociocultural conditions that can promote or hinder fruitful personal development (Reeve et al., 2004). In relation to SDT and physical activity, Vallerand $(1997,2007)$ emphasizes the importance of contextual and situational factors where factors such as interpersonal relations and autonomy support are linked to three innate psychological needs influencing the way individuals behave: need for autonomy, need for feeling of competence and need of relatedness (ibid.).

Based on SDT tenets, Vallerand (1997) proposed a model of motivational processes (social factors psychological mediators motivation consequences) in which different motivational types are influenced by social environment factors supporting or thwarting motivation. Based on this model it should be possible, by autonomy support, to enhance, for example, students' motivation and their behavioural, cognitive and/or affective out- 
comes, which is the last stage (Consequences) of the proposed model. The model is supported by studies (Hagger et al., 2003; Hagger et al., 2005), which have shown how perception of autonomy support in physical education was related to students' reported level of identified regulation and intrinsic motivation in their leisure time influencing both behavioural and affective outcomes. Other studies have shown that environments supporting mastery or task goals are likewise strongly related to more self-determined forms of motivation (Parish \& Treasure, 2003). Further, choice, cooperation and improvement facilitated by a mastery environment can predict relatedness, competence and autonomy, respectively (Ntoumanis, 2001), and influence students' motivation for $\mathrm{PE}$ in a positive manner.

\subsection{Present Study}

While previous motivational research has identified social factors like autonomy support and support of mastery or task goals having important influence on physical education and students'/athletes' motivation and behaviour, the role of peer feedback is still a relatively unexplored social-contextual factor. Based on the refereed research, we propose and introduce a form of giving and receiving peer feedback (a psychosocial mediator) which hypothetically supports the students' autonomy and give them self-control in relation to which competences, within a selected frame, they want to work with. According to Vallerand (1997) these are key issues enhancing the students' motivation and hence resulting in behavioural and affective changes in relation to exercising volleyball. The research question is the following: In which ways do students perceive that an autonomous form of peer feedback in physical education stimulates their motivation for improving volleyball skills by exercising?

\section{Methodology}

\subsection{Participants}

The participants were recruited from a Danish sports folk high school. The school offers a non-formal adult education where young people, normally aged 18 - 30, against payment can attend and follow courses in sport and physical education. For a period of 17 - 44 weeks the attendees live at the school and follow different selfimposed courses of 10 - 17 weeks' duration (e.g., fitness, badminton, volleyball, adventure). In the present study 14 young students (male $=8$, female $=6$, aged 19 - 23) attended a volleyball course for 10 weeks where peer feedback was implemented as pedagogical tool. The volleyball teacher was an experienced physical education teacher and a former elite volleyball player for the Danish national volleyball team. The volleyball unit was a natural part of the students' regular PE program. All of the students participated voluntarily. None of the participants had previously experienced giving and receiving feedback within the PE setting.

\subsection{Design and Procedure}

The project was designed as a case study (Yin, 2009) based on qualitative research methods where action research (McNiff, 2013) provided the basis of implementing peer feedback as a pedagogical tool in PE in a Danish sports folk high school. Prior permission to conduct the study was received from the school headmaster and from the participants in written format. The volleyball lessons (90 minutes each, four times weekly) were divided into exercises with focus on selected skills and peer feedback followed by matches without peer feedback during which the newly acquired skills were tried out. In accordance with the principles of action research (McNiff, 2013), the way peer feedback was handled, the students' attitude and the teacher's guidance and role were discussed among teacher and one of the researchers after each lesson to adjust the implementation of peer feedback in the subsequent lessons. Furthermore, all students were given a logbook with supplementary written information about how to give peer feedback in a specific, constructive and positive manner, and they were asked to write down their inner thoughts and reflections about giving and receiving feedback from a peer after each lesson.

\subsection{Implementation of Peer Feedback}

Initially the students were introduced to peer feedback according to Johnson (2004), Holt, Kinchin and Clarke (2012) and inspired by peer teaching (Siedentop, 1998) and by the reciprocal style and the learner-designed individual program (Mosston \& Ashworth, 2008: 116 and 274) but in a far more autonomous and student-driven 
form. The students were not given task cards or any rubric hand-outs (Iserbyt \& Byra 2013; Johnson, 2004; Mosston \& Ashworth, 2008), but the teacher gave the students a verbal task (regarding elementary or specific volleyball skills), during which the students themselves decided where to focus. In relation to passing in volleyball, it could be, e.g., the bending of the knees or the folding of the hands. This form of free choice was introduced according to Wentzel and Wigfield (2009) and Ntoumanis (2001), who have shown that the students' autonomy is affected in a positive way if they have a possibility of choosing and planning their own activities in the learning of volleyball skills. Furthermore, the students themselves selected a partner for collaboration as companionship in PE has shown that observers/givers in reciprocal style of teaching give specific feedback more frequently and positively to friends, and the doer/receiver feels more comfortable receiving feedback from friends than non-acquaintances (Byra \& Marks, 1993). In addition, positive relationships between peers associated with optimal physical education experiences (Cox \& Ullrich-French, 2010) support the students' self-selection of a partner. As the students all knew the elementary volleyball skills (serving, passing, setting, and spiking) from previous instruction, their challenge was to optimize the performance of these skills in the game by giving and receiving feedback. At the beginning of each lesson, the teacher stated which volleyball skills or part of the volleyball match the students had to work with, and subsequently, the students discussed in peer groups the specific volleyball skills and the individual requirements for improvement. Afterwards they exercised the skill with a specific focus during which the giver of feedback regularly gave adequate, specific and constructive feedback to the receiver. If the giver of feedback had any questions related to the performance, he/she could easily consult the teacher or the researcher for further coaching. During the peer feedback period, the students changed positions. The feedback period lasted for 60 minutes during which the students performed three to four exercises or tasks followed by a regular volleyball match without peer feedback, in which the players used their achieved skills. At the end of each lesson, the students spent 10 minutes writing logbooks. Instruction, peer feedback exercises, volleyball match and writing of logbook took place in the sports hall at the sports folk high school.

\subsection{Empirical Data}

Data were collected as in situ class observations, interviews and students' logbook entries. Observations were made by one of the researchers as unstructured field notes by a participant observer (Launsø \& Rieper, 2005), who took photographs as well. The photographs were used to verify or validate the written field notes taken during the observations and used as stimulate recall (Nunan, 1998) during the student and teacher interviews. The class teacher and eight students (male $=4$, female $=4$ ) were interviewed at the end of the study using a set of semi-structured questions (Halkier, 2012; Kvale, 1994). The teacher was interviewed individually (duration 45 minutes) and the students as a group (focus group interview technique; duration of the interview 60 minutes). All interviews were conducted in the sports hall where the lessons were given. The students' logbook entries served as written self-reports.

\subsection{Analysis}

The data were analysed using primarily the interpretative phenomenology analysis (Palmer et al., 2010; Smith, Flowers, \& Larkin, 2009) in order to identify and extract common themes and patterns. First, the interview transcripts and transcription of the students' logbooks were read and re-read; with meaningful sentences being extracted and coded using the analytic software AtlasTiver 7.0. Common themes were generated by clustering quotes to form categories consistent with a single topic. For method triangulation, these themes were compared with data from field notes and in situ observations to validate the topics and the students' quotations. The identified themes were ordered according to the self-determination theory and the three psychological needs (Deci \& Ryan, 2012) and subsequently discussed in relation to factors influencing the students' motivation according to former research in physical education (Alderman, Beighle, \& Pangrazi, 2006; Ames, 1992; Mandigo \& Holt, 2000; Standage et al., 2007).

\section{Results and Discussion}

The analysis of the students' logbooks and the interview with the students and the teacher revealed eight major themes, which were related to the three innate psychological needs: autonomy, competence and relatedness. 
Together these themes allocate and accentuate the students' perception of how peer feedback influenced their behavioural and affective outcomes, and hence their motivation for exercising volleyball. Furthermore, the themes are comparable with findings from other research projects dealing with motivation and physical education (Alderman, Beighle, \& Pangrazi, 2006; Chen \& Ennis, 2009; Cox \& Ullrich-French, 2010).

\subsection{Autonomy}

One of the major factors related to the self-determination theory affecting the students' motivation in physical education is autonomy (Edmunds \& Ntoumanis, 2007; Layne \& Hastie, 2012). The students perceived autonomy in many different ways; for example, self-selection of collaborates at the beginning of the peer feedback unit or having the possibility themselves to decide where to focus within a specific exercise. The emergent themes were about choice and control in the exercises plus relevance and meaning of the exercises.

\subsubsection{Choice and Control in the Exercises}

The Feedback-guide written in the logbook emphasized that the students themselves had to make a choice; "Ask your peer what s/he would like to focus on and improve in the exercise", but initially it seemed to be very difficult for the students to give and receive feedback compared with traditional teacher-directed teaching. Some of the students expressed confusion and insecurity about having the responsibility for guiding others, but in dialogue with the participant observer and by guidance from the teacher, the students experienced satisfaction in using peer feedback, and after a while they felt that they controlled their own learning experiences which motivated them to continue. They could choose where to focus as each individual controlled the exercise in interaction with a peer. This responsibility and co-determination of the feedback were important factors that motivated the students' behaviour in relation to the activities.

Eric: It was cool. That's what I mean by individual training-it's very specific, when I for example say you need to straighten your arms when passing, we can exercise that the whole day. It's great. You gain a lot (group interview).

Poul: I think it was a nice thing, that we ourselves could decide the focus of the training. When you want to exercise passing or setting, you choose for yourselves-you don't have to exercise things that are very well known (group interview).

Both Eric and Poul were positively affected by the way peer feedback was implemented, highlighting one of the "consequences" in the model of motivational processes proposed by Vallerand (1997) and by that supporting the students' motivation for improving volleyball skills.

As seen in the photos the students were very concentrated and engaged during the exercises where they taught each other to bend down the knees (Figure 1(a) and Figure 1(b)) and to fold the hands correctly (Figure 2(a) and Figure 2(b)) when they were to execute passes in volleyball. The observations support findings from other studies (Goudas et al., 1995; Morgan \& Carpenter, 2002; Reeve et al., 2004; Wallhead \& Ntoumanis, 2004) in-

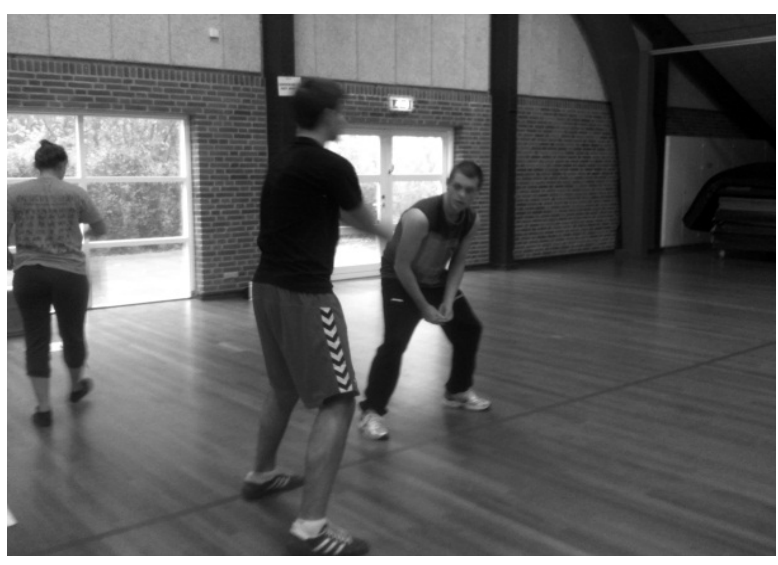

(a)

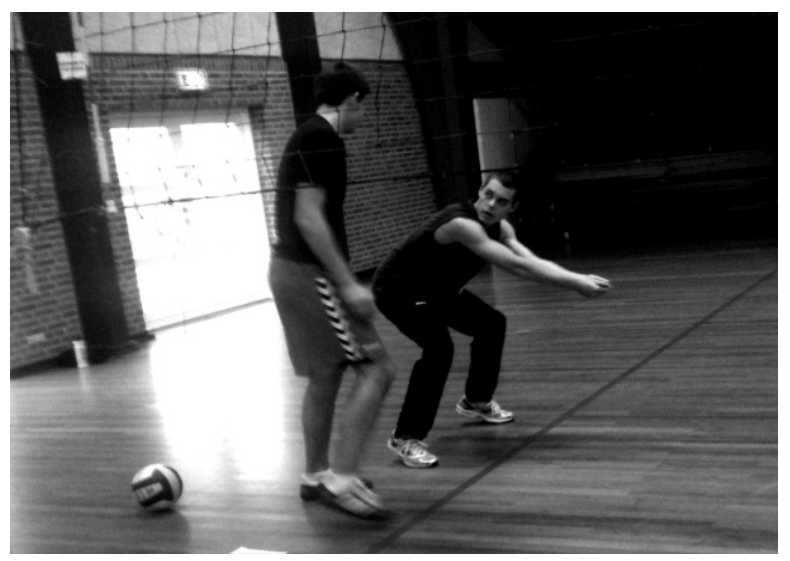

(b)

Figure 1. Two students exercise the position prior to a volleyball pass. The student to right gives feedback. 


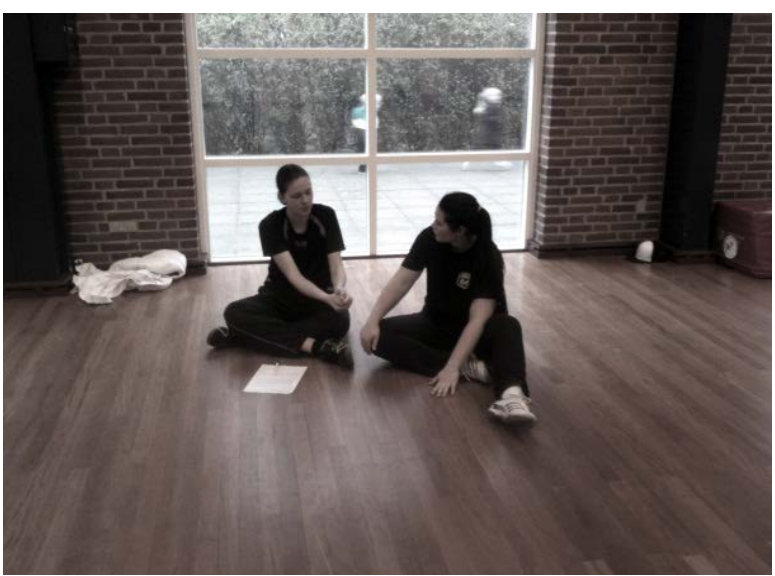

(a)

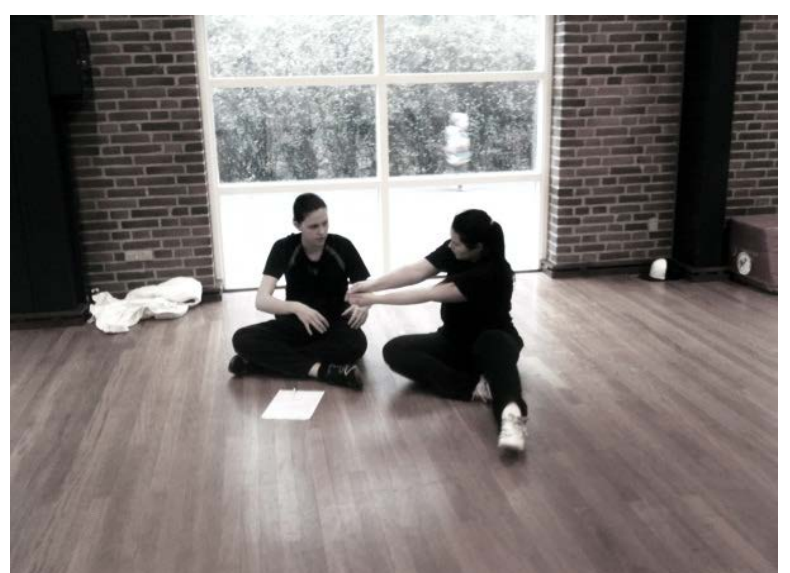

(b)

Figure 2. Two students are discussing the folding of the hands prior to a volleball pass. The student to right gives feedback.

dicating that giving the students the opportunity to make choices and control their own learning strengthens their autonomy and supports intrinsic motivation, and by that their behavioural outcome as seen in the students' concentration in the feedback situation.

\subsubsection{Relevant and Meaningful Tasks}

Relevance and meaningfulness are other themes correlating to the psychological need, autonomy, and matching the other themes, choice and control. If the students themselves choose exercises, control them and decide where to focus, the feedback seems relevant and meaningful. It was remarkable that the students both accentuated the giving and the receiving of feedback as relevant and meaningful; it was not just when they received feedback that they reflected on their positions, for example, how they folded their hands or where to place their feet (see Figure 1, Figure 2). During the volleyball unit, the students experienced that giving and receiving feedback was relevant and meaningful.

Hannah: When our teacher just plans the exercise and corrects us if something is wrong, I don't think I notice it as well as I do when it comes from my pal. I can tell what I want her to focus on and it makes me think a lot more afterwards. And when I give feedback, it makes me think twice- - what does my partner do, and, strictly speaking, what do I do in the same exercise. It makes sense... (group interview).

Claude: It is like watching a video... As I saw John jumping when he performed a pass, I could see myself... I'm jumping as well... It is not very good... before I didn't know what went wrong in my passes and how to correct myself, but by instructing John, I realized what I have to do (group interview).

These statements indicate that not only was it important to observe and give feedback to correct a peer, but also watching the performance of others giving feedback influenced the way observers perceived their own performance and influenced their behaviour. The feedback mechanism makes it meaningful and relevant for both parts, and furthermore, connects to the students' self-referenced goals or tasks.

Eric: I think it's like having a personal coach. It's cool to have our own coach, and I think that's what it's like here (group interview).

Adam: After using this method [peer feedback], I have felt a remarkable improvement... my passes are twice as good as in the beginning (group interview).

It seems clear that peer feedback with self-chosen focus and relevance has had affective impact on the two students. Then it can be discussed whether Adam's passes have improved because of peer feedback as the same improvement could have resulted from the exercises alone, but it was definitely an advantage that he could choose to focus on passes as he felt it was relevant to him to exercise and by that made PE meaningful for him. In a teacher-structured session, it can be difficult to meet all the students' needs and expectations for what is relevant for each individual, so in that sense, peer feedback has an advantage.

The findings in the above-mentioned categories are supported by a study of peer influence on exercise en- 
joyment (Murcia et al., 2008) focusing on the task-involving climate among non-competitive exercisers from 30 sports centres. As task involvement can be related to individual choice, control, relevance and meaning (Nicholls, 1984), the study concluded that working with peers relates to autonomy and competences, stating "A climate in which peers place more emphasis on personal progress and effort will enable exercisers to enjoy the exercise sessions" (Murcia et al., 2008: 29). By using peer feedback, the students in the present project emphasised progress and effort, and they expressed enhanced enjoyment of the exercise.

Elisabeth: I feel that I have improved in playing volleyball [with help from my peer]... and it is more fun to play now that I can control the ball... I want to become even better (group interview).

\subsection{Competences}

Another major factor influencing the students' motivation is the perceived competence in relation to the challenges they meet (Ferrer-Caja \& Weiss, 2000; Hein \& Koka, 2007). In the interview with the students, several statements indicated that it is important that volleyball skills and competences are interconnected to enhance the students' behavioural and affective outcome in a positive way, thus enhancing their motivation for doing volleyball exercises. In the last section there were many quotations regarding improvement of volleyball skills supporting the behavioural outcome of the implemented peer feedback (Vallerand, 1998). Specifically in the last quotation, Elisabeth accentuates that her competence as a volleyball player has improved as she can now control the ball, and by that her motivation for playing and learning volleyball has been enhanced. Another theme, which emerged regarding competences, was the challenges confronting the students in the exercises

\section{Optimal Challenges, Autonomy and Improving of Skills}

One way that the students can maintain or improve their competences is by seeking or meeting challenges in the exercises. According to Csikszentmihalyi (1990) and Jackson and Csikszentmihalyi (1999), the students need to experience optimal challenges in relation to their skills to feel flow or to be motivated to continue exercising. However, this optimal challenge cannot stand alone as argued by Ryan and Deci (2007: 3), "an optimal challenge that is not accompanied by feelings of autonomy will not prompt intrinsic motivation". They argue that the challenge has to be in accordance with the students' choice, be within their control, and in most instances, be self-referenced. As Eric says:

When we used to play beach volley outside, I didn't think I was improving very much, but in this unit, I feel that I am twice as good as in the beginning because my pal challenges me... my motivation for playing volleyball has improved... I'm looking forward to the next session... (group interview).

In accordance with Eric's earlier statements about choice and control, it seems obvious that the challenges met in the volleyball exercises relate to the enhanced perception of motivation. Following Ryan and Deci (2007) both Eric and Elisabeth have met challenges according to self-referenced standards as they had both felt improvement of volleyball skills during the intervention and by that are more motivated to exercise. Research examining perceived competences or expectancy beliefs in physical education supports the results (Ames, 1992; Chen \& Ennis, 2009) stating that challenges and self-referenced standards adopted as indicator of improvement promote students' perception of motivation

\subsection{Relatedness}

Research and theories regarding motivation often focus on the sociocultural context, in which action takes place (Reeve et al., 2004). Therefore, the impact of the third psychological need, relatedness, is very important for the students' perception of motivation. The following theme emerged in relation to the third psychological need: a secure and positive context.

\section{Giving and Receiving Feedback Should Be in a Secure and Positive Context}

It is essential that the context for giving and receiving feedback is secure and positive in that the participants are familiar with each other, the feedback is given with a positive attitude, and it is legitimate to criticise (Archer, 2010). Initially, the students felt insecure because of the unfamiliarity of having to correct their peers, but after a while the students became confident in their peer groups and the mutual feedback felt more natural. 
Hannah: It was strange the first time I had the responsibility to concentrate and give feedback to Elisabeth...

Elisabeth: Yeah... but it was good and I really improved... it was nice to be together in pairs during the unit.

Hannah: I felt secure in your company. Being partners was good in the sense that we knew each other... (group interview).

I the interviews Hannah and Elisabeth expressed pleasure exercising with a peer that they knew and were comfortable with, which we interpret as an affective factor related to the psychological need relatedness and its impact on the intrinsic motivation of students (Ryan \& Deci, 2007; La Guardia \& Ryan, 2002). The following statement from the teacher supported the girls:

The girls were good for each other. All the time they discussed and corrected each other... normally they don't talk to each other, but during this unit they have worked very well... I'm sure they will continue to use each other in the future... (interview, teacher).

Giving and receiving feedback seem to be a matter of mutual respect. Øiestad (2007) argues that giving feedback is about acknowledging some aspects of a person and that receiving feedback is about affirmation and the possibility of development. It follows that good feedback is about being together in a secure and positive context where the students can relax in pairs and be themselves focusing on development in the given activity. The same thoughts were expressed in the logbooks stating the positive tone in feedback as important for the affective feeling of motivation.

We could see both positive and negative aspects in the way we handled the ball, but in feedback we focussed mainly on the positive aspects and that was really motivating (Dan, logbook).

\subsection{Peer Feedback and Pedagogical Challenges}

The results from this study support the findings from others indicating that peer feedback and the following behavioural and affective outcomes have a positive impact on students' perception of motivation (Vazou et al., 2005). Nevertheless, the students and their teacher were confronted with challenges that may create difficulties in working with peer feedback (Ernst \& Byra, 1998). Particularly the receiving and giving of feedback were seen as challenges in the beginning of the peer feedback unit. In the study the students expressed uncertainty about their own abilities, thus showing the importance of backup in the form of teacher assistance when it came to the implementation of peer feedback in PE.

Doris: [talking about giving feedback to her peer]... but then our teacher came and helped me to notice what and how my mate could do better, and so I felt more comfortable next time I had to give feedback... (group interview).

John: [about the uncertainty] Especially in the beginning it was important that Cathrine [the teacher] helped as I didn't know how to stand and that stuff, which is important to know to give correct feedback... (group interview).

A way to assist the students to feel more comfortable when giving peer feedback is by using rubric handouts or task cards as a supplement (Iserbyt \& Byra, 2013; Johnson, 2004; Mosston \& Ashworth, 2008). The cards are valuable tools clearly instructing and modelling the task of the giver and receiver before practice and in this way helping the student at the beginning of the unit. Further, the cards have shown to have an impact on the students' learning in physical education (Iserbyt \& Byra, 2013; Iserbyt, Elen, \& Behets, 2010). In this study we deselected the cards, but maybe they can be used in combination with free choice and control of the exercises.

Another challenge in the volleyball unit was the teacher's lack of experience of peer feedback. As she mentioned very early in the unit, she did not feel comfortable in the situation and felt insecure about what she had to do, which often resulted in "traditional teaching" where she returned to instructing the students about what to do instead of encouraging peer feedback by guiding and informing them about this form of feedback. She rarely addressed her instructions to both students or helped them to guide each other. As she explains in the interview: "It was very difficult in the beginning... I think it's because of my impatience... I felt it was going too slow... and I couldn't find my role...” (teacher, interview). Just as it is necessary to instruct the students to give and re- 
ceive feedback, it is also important to give the students and their teacher time to observe, discuss and find out how peer feedback can work and give benefits (Johnson, 2004). In the present study good results came with time as the teacher admitted:

At the end of the unit in which peer feedback was implemented I think it worked quite well... you could see the students achieved skills... it became a lot easier and suddenly they used volleyball phrases I'm sure I couldn't give them... just because they talked and discussed with each other... so they could ask me questions in a different way than I'm used to (teacher, interview).

Other studies stress other challenges related to peer feedback: the time to exercise is reduced because of the on-going interaction between students, possible disagreements can arise, and the students can spend time "chit-chatting" instead of concentrating on the exercise (Couturier, Chepko, \& Coughlin, 2005; Mosston \& Ashworth, 2008). We did not observe any of the mentioned challenges, but this may relate to the students, their self-election in working with physical education and sport, and the time spent practicing peer feedback. Nevertheless, even though the peer feedback method may have some disadvantages, many studies of physical education, sport and motivation emphasise the benefits of implementing peer feedback and similar methods (e.g. Byra \& Marks, 1993; Dyson, 2002; Ernst \& Byra, 1998; Johnson, 2004; Johnson \& Ward, 2001; Mosston \& Ashworth, 2008).

\subsection{Limitation and Future Research}

There are several limitations of the study. Besides the number of informants and the length of the intervention period, it is the students' approach to the intervention. As they attend the sports folk high school voluntarily, the students in this study are motivated for doing physical education and sports. This in advance positive approach may have affected their attitude towards the peer feedback intervention to be more positive than in other contexts, meaning that the results cannot necessarily be transferred to, for example, a primary school. Future studies in other settings, which may include more students and a prolonged intervention period, are to clarify the connection between peer feedback, free choices in the task, and behavioural and affective outcomes as indicators for motivation.

\section{Conclusion}

In this paper we focused on the impact of peer feedback on students' perception of motivation for improving volleyball skills in physical education. In a volleyball course, 14 students worked with peer feedback in a manner where they themselves decided where to focus in the given tasks. Our results showed that this type of feedback influenced the students' behavioural and affective outcomes in the volleyball unit and by that their motivation for improving volleyball skills. We found that the following factors had impact on the students' motivation: choice and control in relation to peer feedback, the meaning and relevance of the exercises, the challenges in the feedback situation, and finally the positive and secure context, in which the feedback was exchanged. Further, we argued that the factors affecting the students' behaviour and attitude for exercising and playing volleyball are related to the innate psychological needs, autonomy, competences and relatedness, which according to the selfdetermination theory supports the students' motivation.

\section{References}

Alderman, B. L., Beighle, A., \& Pangrazi, R. P. (2006). Enhancing Motivation in Physical Education. Journal of Physical Education, Recreation \& Dance, 77, 41-45. http://dx.doi.org/10.1080/07303084.2006.10597828

Ames, C. (1992). Achievement Goals, Motivational Climate, and Motivational Processes. In G. C. Roberts (Ed.), Motivation in Sport and Exercise (pp. 161-176). Champaign, IL: Human Kinetics Books.

Archer, J. C. (2010). State of the Science in Health Professional Education: Effective Feedback. Medical Education, 44, 101108. http://dx.doi.org/10.1111/j.1365-2923.2009.03546.x

Byra, M., \& Marks, M. C. (1993). The Effect of two Pairing Techniques on Specific Feedback and Comfort Levels of Learners in the Reciprocal Style of Teaching. Journal of Teaching in Physical Education, 12, 286-300.

Chen, A., \& Ennis, C. D. (2009). Motivation and Achievement in Physical Education. In K. R. Wentzel, \& A. Wigfield (Eds.), Handbook of Motivation at School (pp. 553-574). New York: Routledge. 
Couturier, L. E., Chepko, S., \& Coughlin, M. A. (2005). Student Voices-What Middle and High School Students Have to Say about Physical Education. Physical Educator, 62, 170-177.

Cox, A. E., Smith, A. L., \& Williams, L. (2008). Change in Physical Education Motivation and Physical Activity Behavior during Middle School. Journal of Adolescent Health, 43, 506-513. http://dx.doi.org/10.1016/j.jadohealth.2008.04.020

Cox, A. E., \& Ullrich-French, S. (2010). The Motivational Relevance of Peer and Teacher Relationship Profiles in Physical Education. Psychology of Sport and Exercise, 11, 337-344. http://dx.doi.org/10.1016/j.psychsport.2010.04.001

Csikszentmihalyi, M. (1990). FLOW: The Psychology of Optimal Experience. New York: Harper \& Row.

D’Arripe-Longueville, F., Gernigon, C., Huet, M. L., Cadopi, M., \& Winnykamen, F. (2002). Peer Tutoring in a Physical Education Setting: Influence of Tutor Skill Level on Novice Learners' Motivation and Performance. Journal of Teaching in Physical Education, 22, 105-123.

Deci, E. L., \& Ryan, R. M. (2012). Motivation, Personality and Development within Embedded Social Contexts: An Overview of Self-Determination Theory. In R. M. Ryan (Ed.), The Oxford Handbook of Human Motivation (pp. 85-110). Oxford: Oxford University Press.

Dyson, B. (2002). The Implementation of Cooperative Learning in an Elementary Physical Education Program. Journal of Teaching in Physical Education, 22, 69-85.

Edmunds, J. K., \& Ntoumanis, N. (2007). Perceived Autonomy Support and Psychological Need Satisfaction in Exercise. In M. Hagger, \& N. Chatzisarantis (Eds.), Intrinsic Motivation and Self-Determination in Exercise and Sport (pp. 35-51). Champaign, IL: Human Kinetics.

Ernst, M., \& Byra, M. (1998). Pairing Learners in the Reciprocal Style of Teaching: Influence on Student Skill, Knowledge and Socialization. Physical Educator, 55, 24-37.

Ferrer-Caja, E., \& Weiss, M. R. (2000). Predictors of Intrinsic Motivation among Adolescent Students in Physical Education. Research Quarterly for Exercise and Sport, 71, 267-279. http://dx.doi.org/10.1080/02701367.2000.10608907

Gottfried, A. E., Fleming, J. S., \& Gottfried, A. W. (2001). Continuity of Academic Intrinsic Motivation from Childhood through Late Adolescence: A Longitudinal Study. Journal of Educational Psychology, 93, 3-13. http://dx.doi.org/10.1037/0022-0663.93.1.3

Goudas, M., Biddle, S., Fox, K., \& Underwood, M. (1995). It Ain’t What You Do, It’s the Way That You Do It! Teaching Style Affects Children's Motivation in Track And Field Lessons. Sport Psychologist, 9, 254-254.

Gutiérrez, M., Ruiz, L. M., \& López, E. (2010). Perceptions of Motivational Climate and Teachers’ Strategies to Sustain Discipline as Predictors of Intrinsic Motivation in Physical Education. The Spanish Journal of Psychology, 13, 597-608. http://dx.doi.org/10.1017/S1138741600002274

Hagger, M. S., Chatzisarantis, N. L., Barkoukis, V., Wang, C., \& Baranowski, J. (2005). Perceived Autonomy Support in Physical Education and Leisure-Time Physical Activity: A Cross-Cultural Evaluation of the Trans-Contextual Model. Journal of Educational Psychology, 97, 376-390. http://dx.doi.org/10.1037/0022-0663.97.3.376

Hagger, M. S., Chatzisarantis, N. L., Culverhouse, T., \& Biddle, S. J. (2003). The Processes by Which Perceived Autonomy Support in Physical Education Promotes Leisure-Time Physical Activity Intentions and Behavior: A Trans-Contextual Model. Journal of Educational Psychology, 95, 784-795. http://dx.doi.org/10.1037/0022-0663.95.4.784

Halkier, B. (2012). Fokusgrupper. Roskilde: Roskilde Universitetsforlag.

Hein, V., \& Koka, A. (2007). Perceived Feedback and Motivation in Physical Education and Physical Activity. In M. Hagger, \& N. Chatzisarantis (Eds.), Intrinsic Motivation and Self-Determination in Exercises and Sport (pp. 127-140). Champaign, IL: Human Kinetics.

Holt, J. E., Kinchin, G., \& Clarke, G. (2012). Effects of Peer-Assessed Feedback, Goal Setting and a Group Contingency on Performance and Learning by 10 - 12-Year-Old Academy Soccer Players. Physical Education and Sport Pedagogy, 17, 231-250. http://dx.doi.org/10.1080/17408989.2012.690568

Iserbyt, P., \& Byra, M. (2013). Design and Use of Task Cards in the Reciprocal Style of Teaching: Easy to Create and Implement, Task Cards Support Student Learning in Various Content Areas. Journal of Physical Education, Recreation \& Dance, 84, 20-26. http://dx.doi.org/10.1080/07303084.2013.757187

Iserbyt, P., Elen, J., \& Behets, D. (2010). Instructional Guidance in Reciprocal Peer Tutoring with Task Cards. Journal of Teaching in Physical Education, 29, 38-53.

Jackson, S. A., \& Csikszentmihalyi, M. (1999). Flow in Sports. Champaign, IL: Human Kinetics.

Jõesaar, H., Hein, V., \& Hagger, M. S. (2011). Peer Influence on Young Athletes’ Need Satisfaction, Intrinsic Motivation and Persistence in Sport: A 12-Month Prospective Study. Psychology of Sport and Exercise, 12, 500-508. http://dx.doi.org/10.1016/j.psychsport.2011.04.005 
Johnson, M., \& Ward, P. (2001). Effects of Classwide Peer Tutoring on Correct Performance of Striking Skills in 3rd Grade Physical Education. Journal of Teaching in Physical Education, 20, 247-263.

Johnson, R. (2004). Peer Assessments in Physical Education. Journal of Physical Education, Recreation \& Dance (JOPERD), 75, 33-40. http://dx.doi.org/10.1080/07303084.2004.10607287

Kvale, S. (1994). Interview. Copenhagen: Hans Reitzels Forlag.

La Guardia, J., \& Ryan, R. (2002). What Adolescents Need. In F. Pajares, \& T. C. Urdan (Eds.), Academic Motivation of Adolescents (pp. 193-219). New York: Information Age Publishing Inc.

Ladd, G., Herald-Brown, S., \& Kochel, K. (2009). Peers and Motivation. In K. R. Wentzel, \& A. Wigfield (Eds.), Handbook of Motivation at School (pp. 323-348). New York: Routledge.

Launsø, L., \& Rieper, R. (2005). Forskning Med og Om Mennesker. Copenhagen: Nyt Nordisk Forlag Arnold Busck.

Layne, T., \& Hastie, P. (2012). Student and Teacher Responses to a High Autonomy Climate in Physical Education within a Sport Education Season. Revue phénEPS / PHEnex Journal, 4, 1-13.

Mandigo, J. L., \& Holt, N. L. (2000). Putting Theory into Practice: How Cognitive Evaluation Theory Can Help Us Motivate Children in Physical Activity Environments. Journal of Physical Education, Recreation \& Dance, 71, 44-49. http://dx.doi.org/10.1080/07303084.2000.10605984

Martin, E. H., Rudisill, M. E., \& Hastie, P. A. (2009). Motivational Climate and Fundamental Motor Skill Performance in a Naturalistic Physical Education Setting. Physical Education and Sport Pedagogy, 14, 227-240. http://dx.doi.org/10.1080/17408980801974952

McNiff, J. (2013). Action Research (3rd ed.). London: Routledge.

Morgan, K., \& Carpenter, P. (2002). Effects of Manipulating the Motivational Climate in Physical Education Lessons. European Physical Education Review, 8, 207-229.

Murcia, J. A. M., de San Román, M. L., Galindo, C. M., Alonso, N., \& González-Cutre, D. (2008). Peers’ Influence on Exercise Enjoyment: A Self-Determination Theory Approach. Journal of Sports Science and Medicine, 7, 23-31.

Nicholls, J. G. (1984). Achievement Motivation: Conceptions of Ability, Subjective Experience, Task Choice and Performance. Psychological Review, 91, 328-346. http://dx.doi.org/10.1037/0033-295X.91.3.328

Ntoumanis, N. (2001). A Self-Determination Approach to the Understanding of Motivation in Physical Education. British Journal of Educational Psychology, 71, 225-242. http://dx.doi.org/10.1348/000709901158497

Nunan, D. (1998). Research Methods in Language Learning (7th ed.). Cambridge: Cambridge University Press.

Palmer, M., Larkin, M., de Visser, R., \& Fadden, G. (2010). Developing an Interpretative Phenomenological Approach to Focus Group Data. Qualitative Research in Psychology, 7, 99-121. http://dx.doi.org/10.1080/14780880802513194

Parish, L. E., \& Treasure, D. C. (2003). Physical Activity and Situational Motivation in Physical Education: Influence of the Motivational Climate and Perceived Ability. Research Quarterly for Exercise and Sport, 74, 173-182. http://dx.doi.org/10.1080/02701367.2003.10609079

Parker, M., \& Sharpe, T. (1995). Peer Tutoring-An Effective Coaching Tool. Journal of Physical Education, Recreation \& Dance, 66, 50-55. http://dx.doi.org/10.1080/07303084.1995.10607144

Reeve, J., Deci, E. L., \& Ryan, R. M. (2004). Self-Determination Theory: A Dialectic Framework for Understanding Sociocultural Influences on Student Motivation. In D. McInerney, \& S. Van Etten (Eds.), Big Theory Revisited (pp. 31-60). Connecticut: Information Age Publishing.

Ross, R., Freeman, J. A., \& Janssen, I. (2000). Exercise Alone Is an Effective Strategy for Reducing Obesity and Related Comorbidities. Exercise and Sport Sciences Reviews, 28, 165-170.

Ryan, R. M., \& Deci, E. L. (2007). Active Human Nature: Self-Determination Theory and the Promotion and Maintenance of Sport, Exercise and Health. In M. Hagger, \& N. Chatzisarantis (Eds.), Intrinsic Motivation and Self-Determination in Exercise and Sport (pp. 1-20). Champaign, IL: Human Kinetics.

Siedentop, D. (1998). What Is Sport Education and How Does it Work? Journal of Physical Education, Recreation \& Dance, 69, 18-20. http://dx.doi.org/10.1080/07303084.1998.10605528

Smith, J. A., Flowers, P., \& Larkin, M. (2009). Interpretative Phenomenological Analysis: Theory, Method and Research. London: Sage Publications.

Standage, M., Gillison, F., \& Treasure, D. C. (2007). Self-Determination and Motivation in Physical Education. In M. Hagger, \& N. Chatzisarantis (Eds.), Intrinsic Motivation and Self-Determination in Exercise and Sport (pp. 71-86). Champaign, IL: Human Kinetics.

Strong, W. B., Malina, R. M., Blimkie, C. J., Daniels, S. R., Dishman, R. K., Gutin, B. et al. (2005). Evidence Based Physical Activity for School-Age Youth. The Journal of Pediatrics, 146, 732-737.

http://dx.doi.org/10.1016/j.jpeds.2005.01.055 
Vallerand, R. J. (1997). Toward a Hierarchical Model of Intrinsic and Extrinsic Motivation. Advances in Experimental Social Psychology, 29, 271-360. http://dx.doi.org/10.1016/S0065-2601(08)60019-2

Vallerand, R. J. (2007). A Hierarchical Model of Intrinsic and Extrinsic Motivation for Sport and Physical Activity. In M. Hagger, \& N. Chatzisarantis (Eds.), Intrinsic Motivation and Self-Determination in Exercise and Sport (pp. 255-280). Champaign, IL: Human Kinetics.

Vazou, S., Ntoumanis, N., \& Duda, J. L. (2005). Peer Motivational Climate in Youth Sport: A Qualitative Inquiry. Psychology of Sport and Exercise, 6, 497-516. http://dx.doi.org/10.1016/j.psychsport.2004.03.005

Wallhead, T. L., Hagger, M., \& Smith, D. T. (2010). Sport Education and Extracurricular Sport Participation: An Examination Using the Trans-Contextual Model of Motivation. Research Quarterly For Exercise and Sport, 81, 442-455.

Wallhead, T. L., \& Ntoumanis, N. (2004). Effects of a Sport Education Intervention on Students' Motivational Responses in Physical Education. Journal of Teaching in Physical Education, 23, 4-18.

Ward, P., \& Lee, M. A. (2005). Peer-Assisted Learning in Physical Education: A Review of Theory and Research. Journal of Teaching in Physical Education, 24, 205-225.

Wentzel, K., \& Wigfield, A. (2009). Handbook of Motivation at School. New York: Routledge.

Williams, P. T. (2001). Physical Fitness and Activity as Separate Heart Disease Risk Factors: A Meta-Analysis. Medicine and Science in Sports and Exercise, 33, 754-761. http://dx.doi.org/10.1097/00005768-200105000-00012

Xiang, P., Mcbride, R., Guan, J., \& Solmon, M. (2003). Children’s Motivation in Elementary Physical Education: An Expectancy-Value Model of Achievement Choice. Research Quarterly For Exercise and Sport, 74, 25-35. http://dx.doi.org/10.1080/02701367.2003.10609061

Yin, R. K. (2009). Case Study Research: Design and Methods (Vol. 5). London: SagePublications Ldt.

Øiestad, G. (2007). Feedback. Copenhagen: Dansk Psykologisk Forlag. 
Scientific Research Publishing (SCIRP) is one of the largest Open Access journal publishers. It is currently publishing more than 200 open access, online, peer-reviewed journals covering a wide range of academic disciplines. SCIRP serves the worldwide academic communities and contributes to the progress and application of science with its publication.

Other selected journals from SCIRP are listed as below. Submit your manuscript to us via either submit@scirp.org or Online Submission Portal.
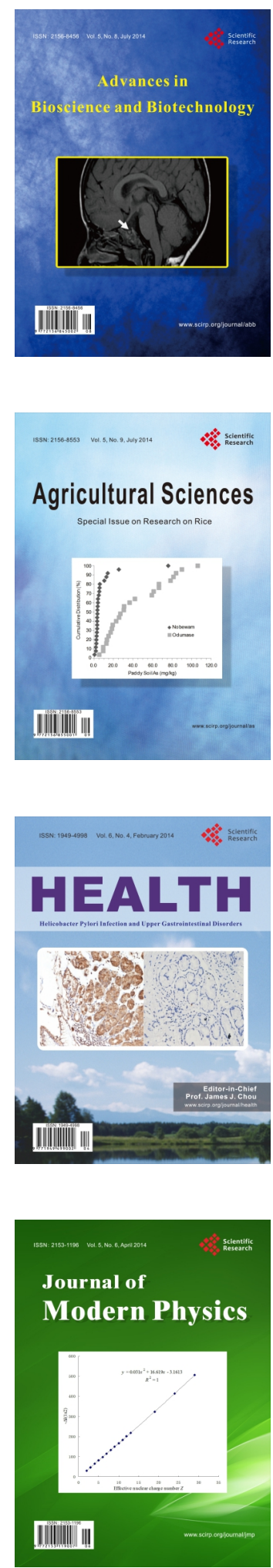
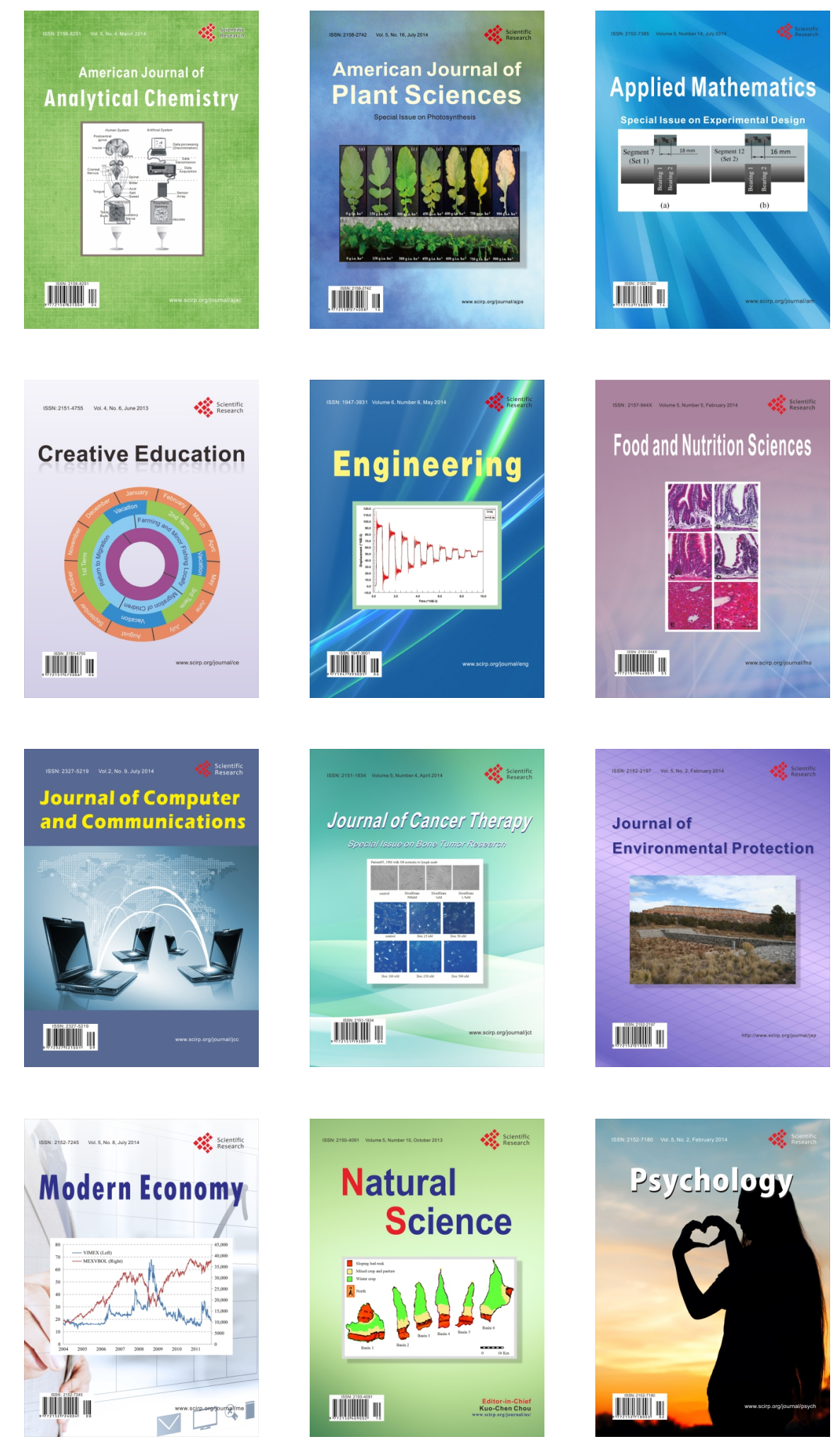